\title{
ANALYSIS OF THE IMPACT OF THE COVID-19 PANDEMIC ON ROAD TRAFFIC ON SELECTED STREET ROUTES IN THE CITY
}

Summary: The temporal and spatial variability of road traffic is influenced by many constant and random factors. The article compares the values of traffic volume before the Covid-19 pandemic, during the introduction of restrictions and at the time of removing restrictions. The results of the analyzes show that the Covid-19 pandemic contributed to the reduction of road traffic in the city.

Keywords: traffic volume, the Covid-19 pandemic, descriptive statistics

\section{ANALIZA WPLYWU PANDEMII COVID-19 NA NATĘŻENIE RUCHU DROGOWEGO NA WYBRANYCH CIĄGACH ULIC W MIEŚCIE}

\begin{abstract}
Streszczenie: Na zmienność czasową oraz przestrzenną natężenia ruchu drogowego ma wpływ wiele czynników stałych oraz losowych. W artykule porównano wartości natężenia ruchu przed pandemią Covid-19, w trakcie wprowadzania obostrzeń oraz w momencie zdejmowania obostrzeń. Wyniki z przeprowadzonych analiz wskazują, że pandemia Covid-19 przyczyniła się do zmniejszenia ruchu drogowego w mieście.
\end{abstract}

Słowa kluczowe: natężenie ruchu drogowego, pandemia Covid-19, statystki opisowe

\section{Introduction}

Traffic volume varies over time and differs between areas on the city's transport network. Road traffic in specific periods is characterized by similar values, with slight fluctuations. These values in a given area of the transport network in the morning or afternoon peak hours, in off-peak periods on working days in each of these periods, fluctuate around similar values [1]. However, traffic is disrupted, when there are

\footnotetext{
1 Silesian University of Technology, Faculty of Transport and Aviation Engineering, Department of Transport Systems, Traffic Engineering and Logistics, agata.kurek@polsl.pl

2 Silesian University of Technology, Faculty of Transport and Aviation Engineering, Department of Transport Systems, Traffic Engineering and Logistics, elzbieta.macioszek@polsl.pl
} 
random or planned events on the roads. The reasons for such a disruption may be i.a.: a road accident, road works [2], the occurrence of public holidays [3], events organized in the city [4].

The covid-19 pandemic broke out in the world in 2020 [5]. An epidemic was declared in Poland on March 20 [6]. This has contributed to changes in the everyday life of every person. National authorities recommended that leaving home should be kept to the minimum necessary to prevent the spread of the virus [7]. In schools and universities, classes were conducted with the use of information systems [8,9]. In companies, where it was possible, employees worked in a remote or hybrid form [10]. Online sales increased as shopping malls, furniture, and DIY stores were temporarily closed and in others, the number of customers was reduced [11]. Traveling by passenger car was recommended, while the number of passengers possible to carry was limited in public transport vehicles [12,13]. In some cities in Poland, there was no obligation to pay a parking fee at parking spaces in the Paid Parking Zone [14,15]. All these activities contributed to changes in the transport behavior of inhabitants in Poland. What caused changes in the distribution of road traffic in cities $[16,17]$. Reducing road traffic due to the covid-19 pandemic also contributed to reducing the negative impact of transport on the natural environment $[18,19]$. The literature on the subject also includes works that investigate the impact of reducing the number of trips on the occurrence of road incidents [20,21].

Conducting research and analysis of the variability of road traffic volume and the factors influencing it, allow learning about the patterns of communication behavior of inhabitants. Thanks to this, it is possible to design and build appropriate road infrastructure. In addition, the knowledge of the communication behavior of travelers allows managing traffic in the city thanks to, e.g. elements of Intelligent Transport Systems.

The article aims to analyze the impact of the covid-19 pandemic on the traffic volume on selected street routes in the city. The article consists of 4 parts. The characteristics of the research area and the performed measurements are presented in the second chapter, after the introduction. The next part presents the results of the analysis of the impact of the covid-19 pandemic on road traffic on selected street routes in the city of Gliwice. The analysis used data from the Traffic Control Center in Gliwice for 3 street routes. Graphs of comparison of 3 selected weeks were developed: before the pandemic, during the introduction of restrictions, and at the time of removal of the restrictions in 2020 and the corresponding ones in 2019. Then, box plots were prepared for the data, which made it possible to evaluate changes in road traffic in the analyzed weeks in 2019 and 2020 based on the values of descriptive statistics. The article ends with conclusions from the analyzes carried out.

\section{Characteristics of the research area and conducted research}

Gliwice is a city in the Silesian Voivodeship. There were 715.2 cars per 1000 inhabitants in the city in 2020 [22].

Three street routes in Gliwice were selected for the study (Fig. 1). Selected streets are important communication routes in Gliwice. Pszczyńska Street connects the A1 and A4 motorway exit with the city center. Rybnicka Street allows traveling from the A4 
motorway to the city center and Tarnogórska Street from the A1 motorway. The data was obtained from the Traffic Control Center in Gliwice.

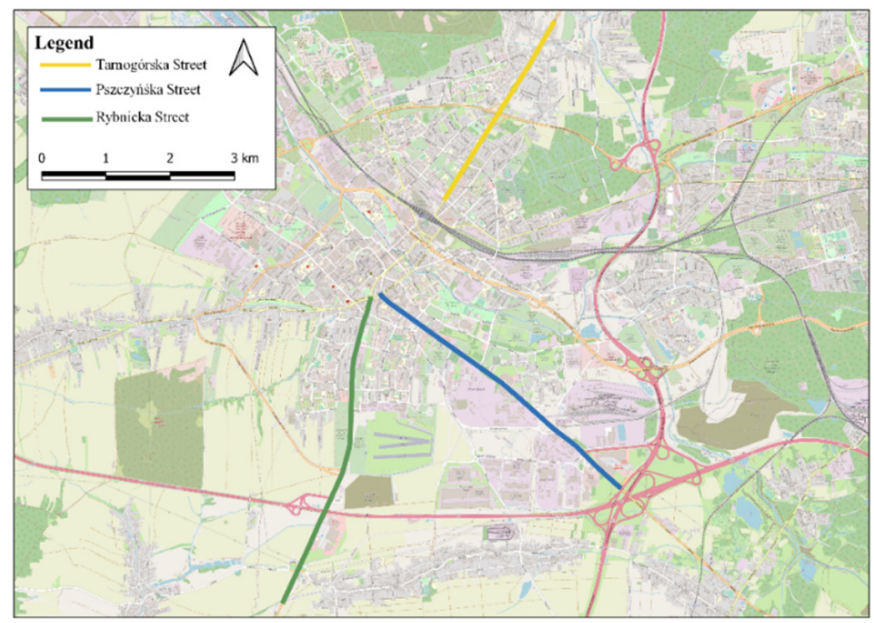

Figure 1. Location of the studied streets against the background of the city Gliwice

Cameras located at the beginning and end of the measuring section count the vehicles going straight in both directions. For the analysis, no directions were distinguished, the examined values are the sum of the traffic volume in both directions. The obtained data included the number of cars passing per minute each day from January to June 2019 and 2020. The data was aggregated to an hour to avoid fluctuations in traffic volumes occurring in shorter periods of the analysis [23].

3 weeks were selected for the analysis, in which there were no public holidays and no public holidays in the week before and after. In 2020, they were:

- before covid-19 pandemic - $7^{\text {th }}$ week (10.-16.02.2020);

- after the introduction of restrictions in connection with the covid-19 pandemic $-13^{\text {th }}$ tydzień (23.-29.03.2020);

- during the removal of restrictions in connection with the covid-19 pandemic, while maintaining the sanitary regime $-26^{\text {th }}$ week $(22 .-28.06 .2020)$.

and the corresponding weeks in 2019:

- $7^{\text {th }}$ week- 11.-17.02.2019;

$-13^{\text {th }}$ week $-25 .-31.03 .2019$;

$-26^{\text {th }}$ week $-24 .-30.06 .2019$.

\section{Analysis of the impact of the covid-19 pandemic on road traffic on selected street routes in Gliwice}

This chapter presents the results of analyzes of the impact of the covid-19 pandemic on the traffic volume on selected street routes in the city of Gliwice. In the first stage of the work, the values of the traffic volume in each hour in 3 weeks were compared: 7, 13, and 26 in 2019 and 2020 for each street separately (Fig. 2-4). In all analyzed streets, the traffic volume values fluctuate on particular days and hours in all analyzed 
weeks. The traffic volume is lower compared to the working days in the case of Saturdays and Sundays. During the morning peaks (06:00-09:00) and afternoon peaks (14:00-17:00) on working days, these values are the highest, and the lowest at night (23:00-04:00). In the $7^{\text {th }}$ week in 2020, the traffic volume values are similar to those in 2019 . In the $13^{\text {th }}$ week of 2020 , a decrease in traffic volume is already visible compared to 2019. It was the first full week of lockdown in Poland. In the $26^{\text {th }}$ week of 2020, the traffic volume values are lower than in 2019 , but the difference is not as big as in the case of week 13 . In the $26^{\text {th }}$ week, due to the decreasing number of cases, some of the services were opened. The presented analysis shows that the covid-19 pandemic could contribute to the reduction of road traffic in the city. In the case of Pszczyńska Street, on Tuesday, $13^{\text {th }}$ week in 2020 , on Thursday and Friday, $7^{\text {th }}$ week in 2019, a sudden drop in the value of road traffic can be noticed. Such a decrease can also be observed on Tuesday, $13^{\text {th }}$ week, in 2020 at Tarnogórska Street. This could be due to random fluctuations in traffic volume or the vehicle counting system failure.

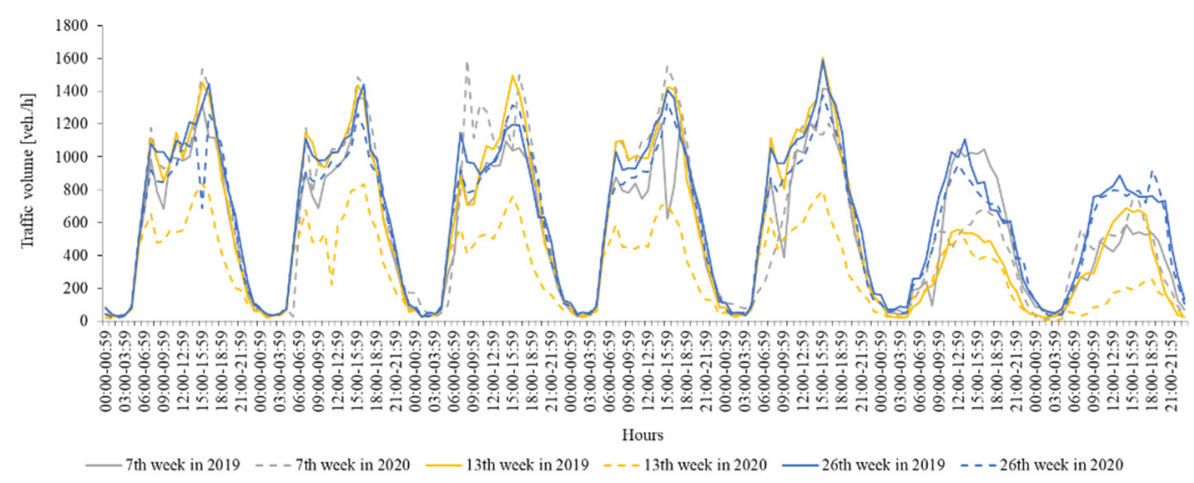

Figure 2. Traffic volume distribution on Pszczynska street in the $7^{\text {th }}, 13^{\text {th }}$ and $26^{\text {th }}$ weeks in 2019 and 2020

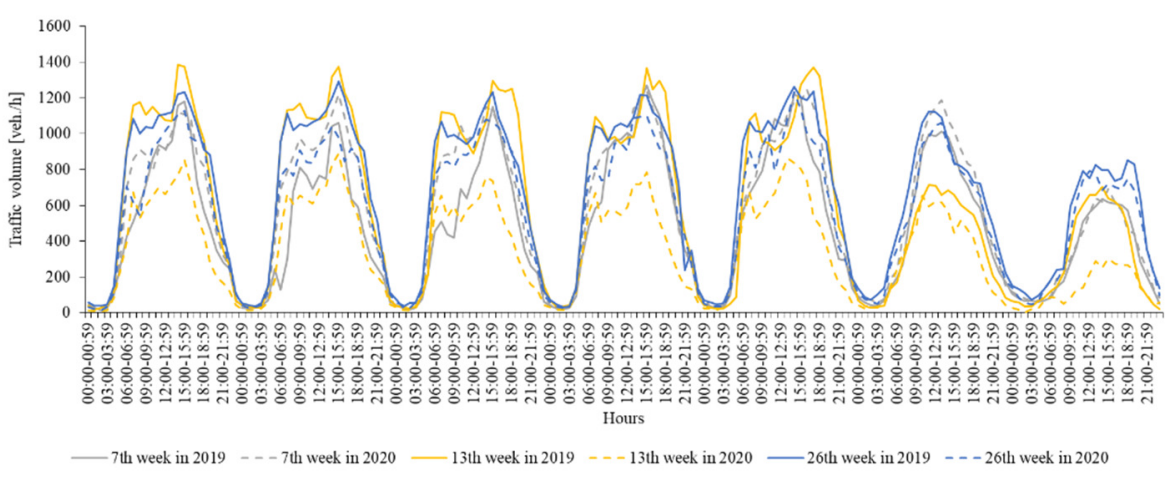

Figure 3. Traffic volume distribution on Rybnicka street in the $7^{\text {th }}, 13^{\text {th }}$ and $26^{\text {th }}$ weeks in 2019 and 2020 


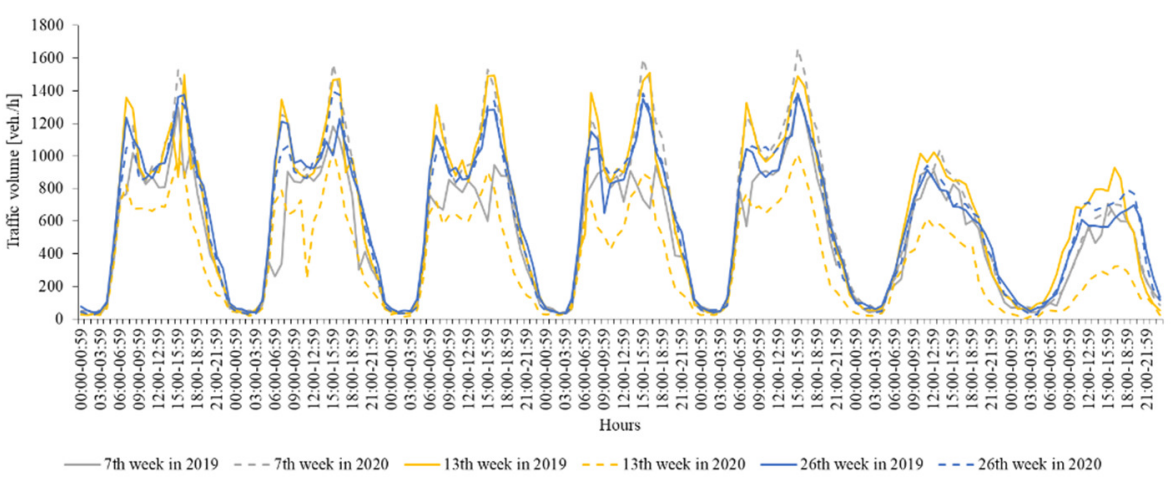

Figure 4. Traffic volume distribution on Tarnogórska street in the $7^{\text {th }}, 13^{\text {th }}$ and $26^{\text {th }}$ weeks in 2019 and 2020

The next stage of the analysis was the development of box plots, which refer to the median, first and third quartile, and minimum and maximum values. Box plots were prepared for each intersection separately, which allows for the analysis of the values of descriptive statistics between particular weeks in 2019 and 2020. Figure 5 shows the box plots for Pszczyńska street. In the $7^{\text {th }}$ week in 2020 before the covid-19 pandemic, the range of minimum and maximum values and the first and third quartile is greater than in 2019. In the case of the $13^{\text {th }}$ week in 2020 , there is a noticeable reduction in the range of minimum and maximum values and the first and third quartile compared to 2019. This week was the first full lockdown week in Poland. In the $26^{\text {th }}$ week in 2020, the range of minimum and maximum values, as well as the first and third quartile, increases compared to the $13^{\text {th }}$ week. In addition, this range is slightly less than the values for the $26^{\text {th }}$ week in 2019. The maximum values are highest in weeks: $7^{\text {th }}$ in $2020,13^{\text {th }}$ and $26^{\text {th }}$ in 2019 .

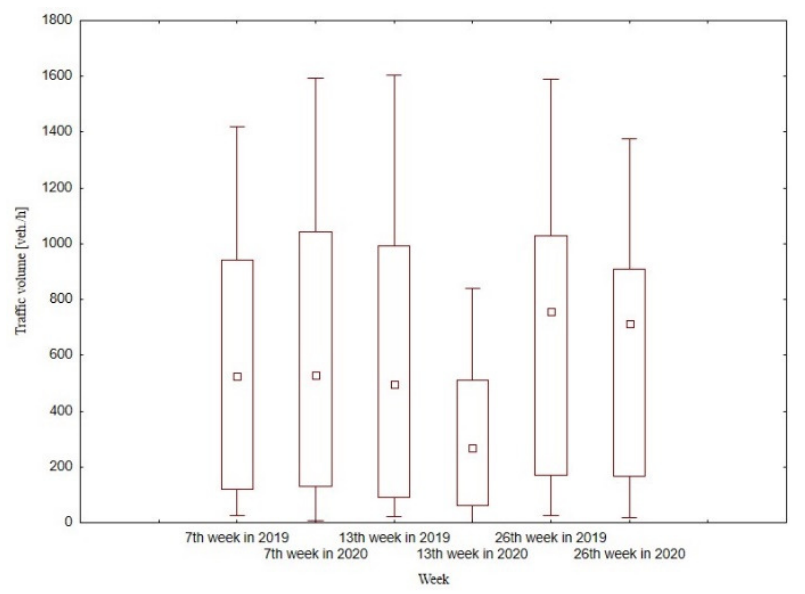

Figure 5. Box plots of traffic volume on Pszczyńska Street in 2019 and 2020

Figure 6 shows box plots for Rybnicka street. The range of first and third quartile values in the $7^{\text {th }}$ week in 2020 is greater than in 2019 as in the case of Pszczyńska street. In the $13^{\text {th }}$ week in 2020 , the range of minimum and maximum values, as well 
as the first and third quartile, is again much smaller than in 2019. In the $26^{\text {th }}$ week of 2020, the approaching values of the minimum and maximum range, as well as the first and third quartile, can be noticed. The maximum values are the highest in all analyzed weeks $\left(7^{\text {th }}, 13^{\text {th, }}\right.$ and $\left.26^{\text {th }}\right)$ in 2019.

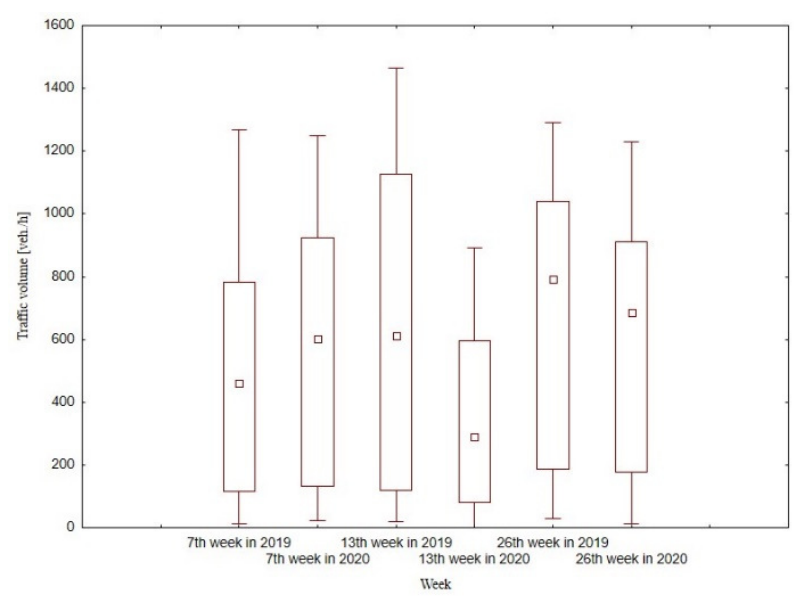

Figure 6. Box plots of traffic volume on Rybnicka Street in 2019 and 2020

Figure 7 shows the box plots for Tarnogórska Street. In the $7^{\text {th }}$ week of 2020 , the range of the minimum and maximum values is much larger than in 2019. The scope of values of the first and third quartile in 2020 is also greater than in 2019. In the $13^{\text {th }}$ week of 2020 , the values of the range of minimum and maximum values and the first and third quartile decrease compared to 2020 . In the $26^{\text {th }}$ week of 2020 , the range of minimum and maximum values, as well as the first and third quartile, is slightly larger than in 2019. The maximum values are the highest in all analyzed weeks: $7^{\text {th }}, 26^{\text {th }}$ in 2020 , and $13^{\text {th }}$ in 2019.

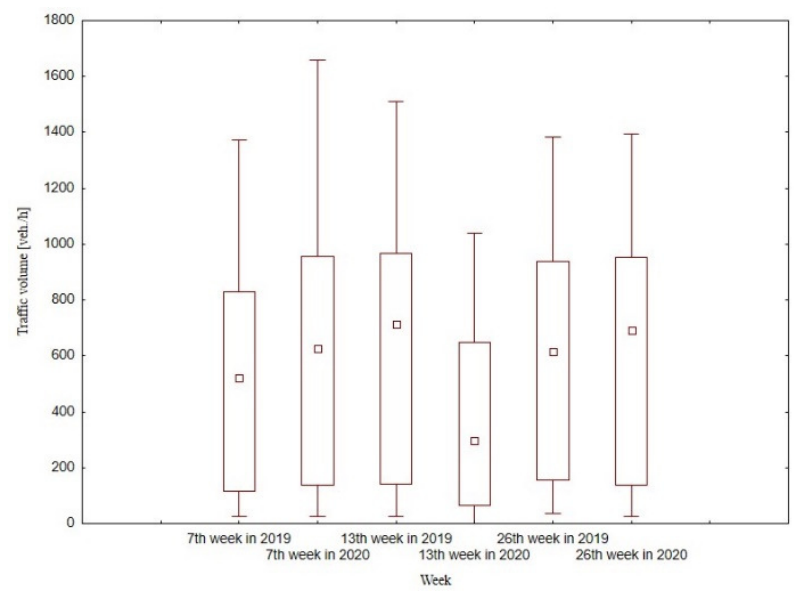

Figure 7. Box plots of traffic volume on Tarnogórska Street in 2019 and 2020 


\section{Conclusions}

The article aimed to analyze the impact of the covid-19 pandemic on the traffic volume on selected street routes in the city. Based on the analyzes carried out, the following conclusions can be drawn:

- The presented review of works indicates that the covid-19 pandemic influenced everyday life in countries around the world, which in turn contributed to a change in the communication behavior of inhabitants;

- The initial increase in the value of traffic volume on the analyzed streets in 2020 (before the pandemic) compared to 2019 is a natural phenomenon, related to an increase in the motorization indicator in the city;

- The noticeable large decrease in traffic in the $13^{\text {th }}$ week of 2020 (the first full week of lockdown in Poland) compared to 2019 confirms the assumptions that the covid-19 pandemic influenced the communication behavior of inhabitants;

- The significant increase in the value of traffic volume in the $26^{\text {th }}$ week in 2020 compared to the $13^{\text {th }}$ week in 2020 indicates that the removal of the restrictions related to the covid-19 pandemic contributed to a partial return of communication behavior from before the pandemic. However, the traffic volumes in the $26^{\text {th }}$ week of 2020 are lower than in 2019. Which indicates that there may have been permanent changes in the behavior of inhabitants;

- Although the analyzed streets are located in one city and have the same importance for traffic on the city's transport network, they are characterized by different values of traffic volume and variability over time.

\section{REFERENCES}

1. GACA S., SUCHORZEWSKI W., TRACZ M.: Inżynieria ruchu drogowego. Teoria i praktyka, Wydanictwo Komunikacji i Łączności, Warszawa 2008.

2. DURCZAK J., MADAJ A.: Zmiany w rozkładzie natężeń ruchu na skrzyżowaniu jako skutek prowadzonych robót budowlanych. Drogownictwo, 7(2019), 214-222.

3. MACIOSZEK E., KUREK A.: Road traffic distribution on public holidays and workdays on selected road transport network elements. Transport Problems, 16(2021)1, 127-138.

4. NI M., HE Q., GAO J.: Using social media to predict traffic flow under special event conditions. In: The 93rd annual meeting of transportation research board, 2014, 1-23.

5. World Health Organization: https://www.who.int/, date of access: 28.09.2021 r.

6. Service of the Republic of Poland: https://www.gov.pl/, date of access: 28.09.2021 r.

7. ZHANG, N., JIA, W., LEI, H., WANG, P., ZHAO, P., GUO, Y., DUNG CH., BU Z., XUE P., ZHANG Y., CHENG R., LI, Y.: Effects of human behavior changes during the coronavirus disease 2019 (COVID-19) pandemic on influenza spread in Hong Kong. Clinical Infectious Diseases, 73(2021)5, 11421150 . 
8. KULIKOWSKI K., PRZYTUŁA S., SUŁKOWSKI Ł.: The motivation of academics in remote teaching during the Covid-19 pandemic in polish universities-Opening the debate on a new equilibrium in elearning. Sustainability, 13(2021)5, 1-16.

9. LUCAS M., NELSON J., SIMS D.: Schools' Responses to COVID-19: Pupil Engagement in Remote Learning. National Foundation for Educational Research, 2020.

10. BRYNJOLFSSON E., HORTON J. J., OZIMEK A., ROCK D., SHARMA G., TUYE H. Y.: COVID-19 and remote work: an early look at US data. National Bureau of Economic Research, (2020)27344, 1-25.

11. ARUMITA A.: Changes in the Structure and System of the Shopping Center Area Due To COVID-19. Available at SSRN https://ssrn.com/abstract=3590973, 2020.

12. JENELIUS E., CEBECAUER M.: Impacts of COVID-19 on public transport ridership in Sweden: Analysis of ticket validations, sales and passenger counts. Transportation Research Interdisciplinary Perspectives, 8(2020), 1-8.

13. PRZYBYLOWSKI A., STELMAK S., SUCHANEK M.: Mobility behaviour in view of the impact of the COVID-19 pandemic-public transport users in Gdansk case study. Sustainability, 13(2021)1, 1-12.

14. Kraków City Roads Authority: https://zdmk.krakow.pl/, date of access: $01.10 .2021 \mathrm{r}$.

15. Municipal Street and Bridge Authority in Chorzów: https://www.mzuim.chorzow.eu/, date of access: 01.10.2021 r.

16. MACIOSZEK E., KUREK A.: Extracting Road Traffic Volume in the City before and during covid-19 through Video Remote Sensing. Remote Sensing, 13(2021)12, 1-38.

17. PARR S., WOLSHON B., RENNE J., MURRAY-TUITE P., KIM K.: Traffic impacts of the COVID-19 pandemic: Statewide analysis of social separation and activity restriction. Natural hazards review, 21(2020)3, 1-10.

18. XIANG J., AUSTIN E., GOUld T., LARSON T., SHIRAI J., LIU Y., MARSHALL J., SETO E.: Impacts of the COVID-19 responses on trafficrelated air pollution in a Northwestern US city. Science of the Total Environment, 747(2020), 1-9.

19. CHEN Z., HAO X., ZHANG X., CHEN F.: Have traffic restrictions improved air quality? A shock from COVID-19. Journal of cleaner production, 279(2021), $1-14$.

20. SALADIÉ Ò., BUSTAMANTE E., GUTIÉRREZ A.: COVID-19 lockdown and reduction of traffic accidents in Tarragona province, Spain. Transportation research interdisciplinary perspectives, 8(2020), 1-10.

21. YASIN Y. J., GRIVNA M., ABU-ZIDAN F. M.: Global impact of COVID-19 pandemic on road traffic collisions. World journal of emergency surgery, 16(2021)1, 1-14.

22. Statistics Poland: https://bdl.stat.gov.pl/, date of access: 04.10.2021

23. CHALFEN M., KAMIŃSKA J.: Analiza przestrzenno-czasowej zmienności natężenia ruchu na Autostradowej Obwodnicy Wrocławia. Logistyka, 3(2014), 971-981. 